\title{
Marijuana smoke hazardous, says CMA, plus more news from the annual meeting
}

$\mathrm{M}$ edical marijuana was one of several hotly debated issues put forward by delegates at the 147th Canadian Medical Association (CMA) annual meeting on Aug. 20.

Attendees approved two delegate resolutions on the contentious topic: one concerned smoking plant materials and the other concerned the need for comprehensive regulatory standards for authorizing the use of medical marijuana.

Then-CMA President Dr. Louis Hugo Francescutti introduced the former motion to address physicians' concerns about the health risks associated with smoking marijuana. He pointed out that marijuana smoke contains many of the same chemicals as tobacco smoke, and some toxin levels are several times higher. For example, the level of ammonia is twenty-times higher than in tobacco smoke.

"Smoking marijuana may be more harmful than tobacco, with increased levels of tar ... and longer, deeper inhalation," agreed newly minted CMA President Dr. Chris Simpson.

But Dr. Ashley Miller said the prohibitionist stance paints CMA as ideologically motivated. Although she supported the public health message, Miller wanted to see an evidence-based harm reduction policy instead.

Others pointed out that there are better delivery systems, such as vaporizers. As such, it's not worth exposing patients to any level of harm from smoking the drug.

Respirologist Dr. Deborah Hellyer noted that smoking one joint is the equivalent of up to 10 cigarettes. "I firmly believe physicians are here to promote health and ... we should be outspoken on this."

The resolution passed with $66 \%$ of attendees in favour.

The second approved resolution called for licensing bodies to develop comprehensive regulatory standards to guide physicians in prescribing mari-

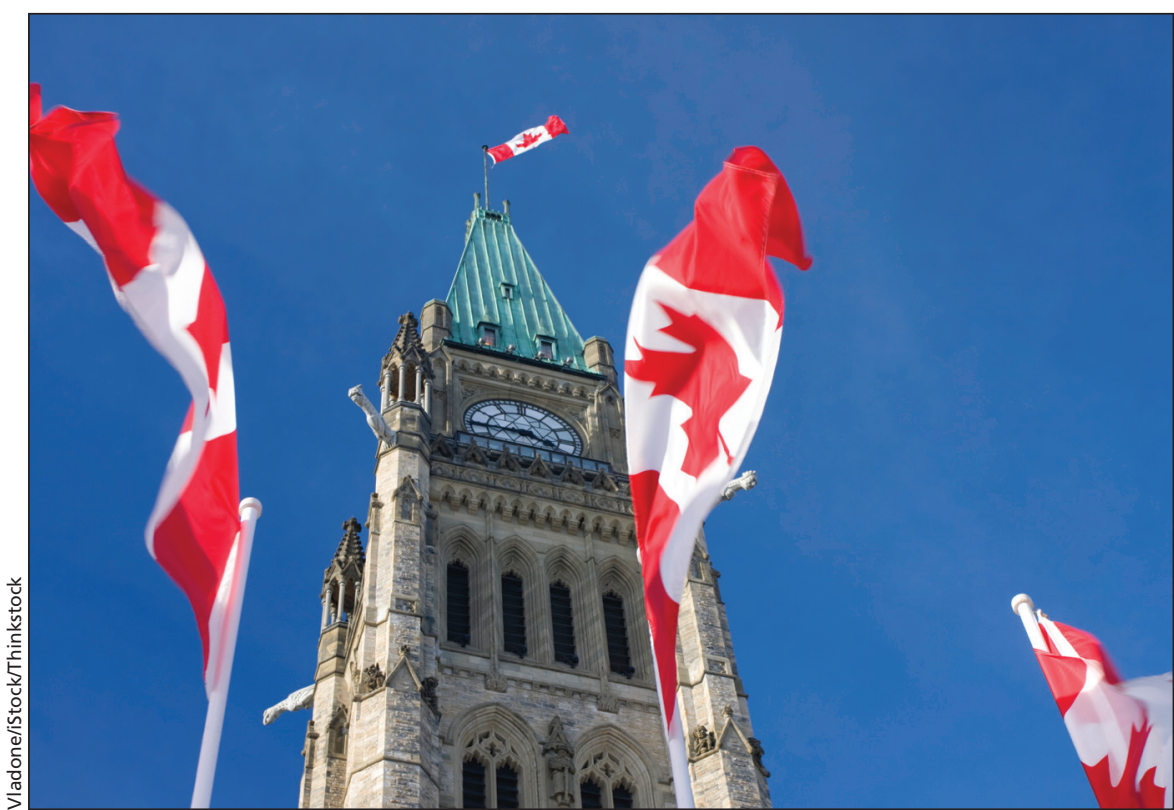

The federal government has charged doctors with administering medicinal marijuana, but delegates agree that doctors need better standards for prescribing the drug.

juana. Currently, some licensing bodies have clear information available; others do not. And policies vary.

Simpson, who moved the resolution, said standardized practices should be adopted by all regulatory colleges in Canada.

Francescutti concurred. "Known risks and benefits must be disclosed," he said. "We need clear and consistent standards."

Other motions, such as one on presumed consent for organ and tissue donation were extensively debated, then defeated. Currently, Canadians sign donor cards to indicate consent, and Canada has one of the lowest donation rates worldwide.

Last year, 256 patients died waiting for organs. "Those lives could have been saved," said Claudia Dandurand Bolduc, a medical student and mover of the resolution.

CMA set a policy just last year that did not favour presumed consent, said Dr. David Gass, who chairs CMA's Committee on Ethics. Gass says presumed consent has a negative connota- tion that could deter some would-be donors. His position was upheld by a recent Ontario survey indicating people did not want presumed consent.

"I think Canadians are generous," said Dr. Laurent Marcoux, who seconded the motion. "Those who don't agree can fill out a card saying they don't agree."

The resolution failed, with $75 \%$ of delegates in opposition.

CMA will reconsider its March 2014 policy on the transmission of HIV in light of a May 2014 Canadian consensus statement that says HIV-positive people on antiretrovirals do not need to advise their sexual partners of their status because of the low risk of transmission.

Delegates also asked CMA to develop policies allowing physicians to take part in credentialling and setting privileges. "It's risky to rely on individuals outside the realm of medicine to develop policies," said the mover, Dr. Charles Webb. "We need to bring literature and data and our own experiences to the table." 
"It's an issue of professionalism," added Dr. Lloyd Oppel, who seconded the motion. It affects all physicians because it sets what doctors do. "Efforts are now well-intentioned, but may lack key insights."

There was some discussion over the merits of a one-size-fits-all policy when issues may differ substantially across the country, but the motion passed nonetheless.

CMA will also propose guidelines to ensure the optimal use of big data while limiting its negative impact on professionalism and confidentiality. "It can be used for multiple reasons," said mover Dr. Ruth Vander-Stelt. "CMA should be proactive on the multiple uses of big data."

Drug shortages were addressed with a call for CMA to recommend that the federal government amend laws and regulations so that in urgent cases medication can be more readily imported into Canada when shortages occur. The problem is with sole-sourced medications, said Dr. Pierre Harvey, the mover. "This should not be tolerated."
A resolution also passed, without discussion, about why a resolution that was defeated last year was acted upon. The motion in question asked for public consultation on medically assisted death. CMA ended up holding town hall meetings across the country. "For me this raises questions about the consequences of our motions and decisions," said mover Dr. Yun Jen of Montréal. Going forward, CMA will establish a working group to examine the process of disposition for resolutions adopted by General Council.

For a complete list of approved motions, visit www.cma.ca.

\section{New president elect}

Delegates also confirmed the election of CMA President-elect Dr. Cindy Forbes, from Waverley, Nova Scotia; her term as president begins August 2015. Forbes has practised as a family physician for 28 years in Nova Scotia and British Columbia.

"My goal as president is to identify and promote innovative solutions and positive change for health care," she stated in a media release. She identified seniors' care and the health care transformation initiative as two areas of engagement.

Forbes is the former president of Doctors Nova Scotia (1996/97) and served on Doctors of British Columbia's Council on Health Care and Promotion, as well as its Tobacco and Illness Prevention Committee. She is also a former Sport Nova Scotia spokesperson for the Sports Makes a Difference Campaign, and has served as Chief Medical Officer for the Bluenose Marathon.

On the national level, Forbes has chaired CMA's Council on Health Care and Promotion, and is a former member of CMA's Political Action Committee. She is also a member of the Doctors Nova Scotia's Master Agreement Steering Committee.

And to save the best news for last, for the first time in 15 years, there will be no increase in CMA fees; they stand at $\$ 495$ annually. - Barbara Sibbald, CMAJ

CMAJ 2014. DOI:10.1503/cmaj.109-4882 